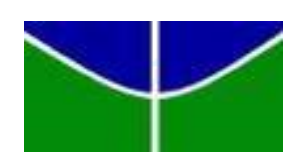

Universidade de Brasília - UnB

Faculdade de Economia, Administração e Contabilidade - FACE

Programa de Pós-Graduação em Economia

Mestrado Profissional em Gestão Econômica de Finanças Públicas

IMPACTO DOS CICLOS POLÍTICOS NAS DESPESAS PÚBLICAS NOS ESTADOS BRASILEIROS

Camila Assunção Rodrigues

Edição Revisada

Brasília-DF

2015 
CAMILA ASSUNÇÃO RODRIGUES

\section{IMPACTO DOS CICLOS POLÍTICOS NAS DESPESAS PÚBLICAS NOS ESTADOS BRASILEIROS}

Dissertação de Mestrado apresentada ao Programa de Pós-Graduação em Economia da Faculdade de Economia, Administração e Contabilidade da Universidade de Brasília, como parte dos requisitos para obtenção do título de Mestre em Economia.

Orientadora: Prof $^{\mathrm{a}}$. Dr ${ }^{\mathrm{a}}$. Andréa Felippe Cabello

Área de concentração: Finanças Públicas 
Universidade de Brasília - UnB

Faculdade de Economia, Administração e Contabilidade - FACE

Programa de Pós-Graduação em Economia

Mestrado Profissional em Gestão Econômica de Finanças Públicas

CAMILA ASSUNÇÃO RODRIGUES

\section{IMPACTO DOS CICLOS POLÍTICOS NAS DESPESAS PÚBLICAS NOS ESTADOS BRASILEIROS}

Dissertação de Mestrado apresentada ao Programa de Pós-Graduação em Economia da Faculdade de Economia, Administração e Contabilidade da Universidade de Brasília, como parte dos requisitos para obtenção do título de Mestre em Economia.

Orientadora: Prof ${ }^{\mathrm{a}}$. Dr ${ }^{\mathrm{a}}$. Andréa Felippe Cabello

Banca Examinadora:

Prof $^{\mathrm{a}}$. Dr ${ }^{\mathrm{a}}$. Andrea Felippe Cabello - Orientadora

Departamento de Economia - FACE/UnB

Profa. Dra. Geovana Lorena Bertussi - Membro Interno

Departamento de Economia - FACE/UnB

Prof. Dr. Antonio Nascimento Júnior - Membro Externo

Departamento de Administração - FACE/UnB

Aprovado em

1 
A Deus, pelo dom da vida. A meus pais, pela dedicação e amor incondicional. 


\section{AGRADECIMENTOS}

Primeiramente, a Deus, por me ensinar a esperar pelo meu tempo, aumentando minhas forças nesta caminhada, me conduzindo pelo melhor caminho, guiando meus passos, aumentando minha fé e renovando cada dia a minha confiança e esperança para que tudo desse certo.

À orientadora Andréa Felippe Cabello, pelo suporte, incentivo e companheirismo em todos os momentos da execução desta pesquisa.

Aos professores Geovana Lorena Bertussi e Antonio Nascimento Júnior, por comporem a banca examinadora e aceitarem o convite sem objeções.

Ao departamento, coordenação e ao programa de pós graduação em economia da Universidade de Brasília.

Aos professores Jevuks Matheus de Araújo e Paulo Amilton Maia Leite Filho pela gentileza dispensada.

A meus pais e irmãs, pelo apoio imensurável e por acreditarem no meu potencial, em todos os momentos da minha vida.

À minha filha canina, Hany, pelo apoio nos momentos que precisei e as palavras (ou latidos) de carinho na hora certa.

Ao meu companheiro Marcelo pela confiança, apoio, dedicação e suporte em todos os momentos da pesquisa.

À pastoral da catequese da Paróquia São Miguel Arcanjo e Santo Expedito, que esteve sempre comigo em oração.

Aos amigos - Gustavo, Luana, Carlos, Carlos Alexandre, Pedro Godinho, Rosita, Juliane, Ana Rachel, Rafael Torres (In Memoriam), Salete, Luiz Carlos, Ariosto, Soraia entre outros - que sempre me apoiaram, seja para discutir, desabafar e apoiar. 
"Cada sonho que você deixa pra trás, é um pedaço do seu futuro que deixa de existir."

Steve Jobs 


\section{RESUMO}

Esta pesquisa propõe analisar a magnitude das despesas públicas dos estados brasileiros no período que compreende os anos de 1995 a 2013 e a relação com o ciclo político, estabelecendo vínculo entre flutuações econômicas e eventos políticos. De acordo com essa perspectiva, os responsáveis pela formulação de políticas baseiam suas decisões com intuito de atender os interesses próprios. A metodologia adotada na pesquisa aborda dados em painel e ferramentas econométricas. Depreende-se, por meio dos resultados, que os ciclos políticos, nas variáveis da despesa pública, podem ser influenciados por considerações eleitoreiras. Neste sentido, os resultados desta pesquisa insinuam que os governantes candidatos à reeleição possuiriam incentivos para manipulação das despesas públicas, direcionando-as para áreas em que seus efeitos sejam mais explicitamente percebidos pelo eleitorado. A análise das despesas públicas revelou a forma e a intensidade do ciclo eleitoral em cada setor. Ou seja, observa-se que o aumento significativo das despesas públicas sugere a criação e a manutenção dos planos e programas de governo, com intuito de prover, ampliar, reestruturar e dar continuidade à assistência à população.

Palavras-chave: ciclos políticos, despesa pública, dados em painel 


\begin{abstract}
This research aims to analyze the public spending by Brazilian states through the years, between 1995 and 2013; and the connection with the political cycle, establishing a link between economic fluctuations and political events. According to this perspective, policy makers base their decisions aiming to meet their own interests. The methodology used in this research approaches panel data and econometric tools. The results demonstrate that political cycles and public spending could be influenced by electioneering aspects. In this sense, the results of this study imply that candidates for government would have got incentives to manipulate public spending, directing them to areas where their effects are more explicitly perceived by the electorate. The analysis of public expenditure revealed the mode and intensity of the electoral cycle in each sector. It can be observed that the significant increase of public spending suggests creation and maintenance of government plans and programs, in order to provide, expand, restructure and continue the assistance to the population.
\end{abstract}

Keywords: cycles political, public expenditure, panel data. 


\section{LISTA DE ABREVIATURAS E SIGLAS}

$\begin{array}{ll}\text { EA } & - \text { Efeitos Aleatórios } \\ \text { EF } & - \text { Efeitos Fixos } \\ \text { IBGE } & - \text { Instituto Brasileiro de Geografia e Estatística } \\ \text { IPEADATA } & - \text { Instituto de Pesquisa Econômica Aplicada } \\ \text { LDO } & - \text { Lei de Diretrizes Orçamentárias } \\ \text { LOA } & - \text { Lei Orçamentária Anual } \\ \text { LRF } & - \text { Lei de Responsabilidade Fiscal } \\ \text { PPA } & - \text { Plano Plurianual } \\ \text { PCB } & - \text { Partido Comunista Brasileiro } \\ \text { PC do B } & - \text { Partido Comunista do Brasil } \\ \text { PDT } & - \text { Partido Democrático Trabalhista } \\ \text { PPS } & - \text { Partido Popular Socialista } \\ \text { PSB } & - \text { Partido Socialista Brasileiro } \\ \text { PSTU } & - \text { Partido Socialista dos Trabalhadores Unificado } \\ \text { PT } & - \text { Partido Trabalhista } \\ \text { PV } & - \text { Partido Verde } \\ \text { SISTN } & - \text { Sistema de Coleta de Dados Contábeis } \\ \text { TSE } & - \text { Tribunal Superior Eleitoral }\end{array}$




\section{LISTA DE GRÁFICOS}

Gráfico 1 - Despesas com Segurança Pública e Defesa Nacional................................. 39

Gráfico 2 - Despesas com Saúde e Saneamento............................................................ 39

Gráfico 3 - Despesas com Educação, Cultura, Desporto e Lazer................................... 39 


\section{LISTA DE TABELAS}

Tabela 1 - Evolução das Teorias de Ciclos Políticos.................................................... 20

Tabela 2 - Estatísticas Descritivas: Estados Brasileiros............................................... 37

Tabela 3 - Resultados dos Modelos Econométricos.................................................. 42 


\section{SUMÁRIO}

1 INTRODUÇÃO ............................................................................................................................ 13

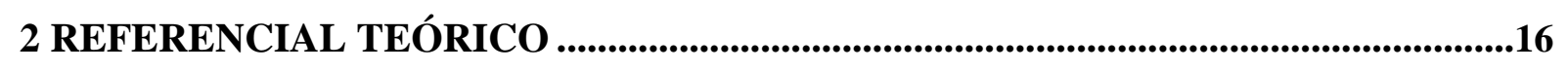

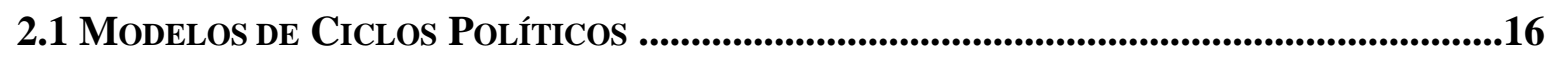

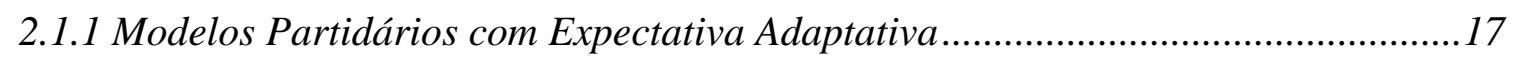

2.1.2 Modelos Oportunistas com Expectativa Adaptativa ............................................ 18

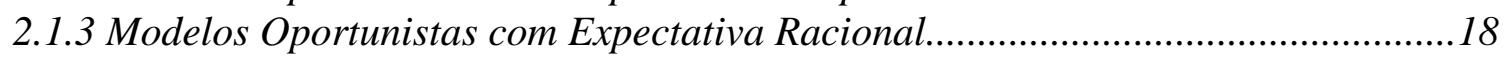

2.1.4 Modelos Partidários com Expectativa Racional ..................................................... 19

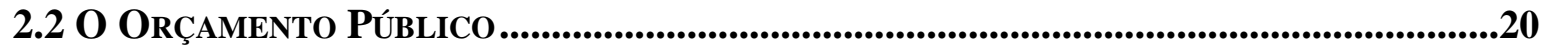

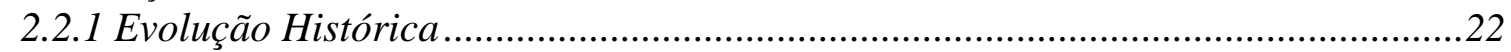

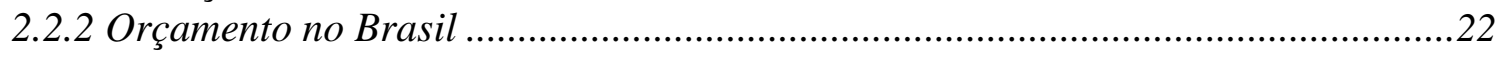

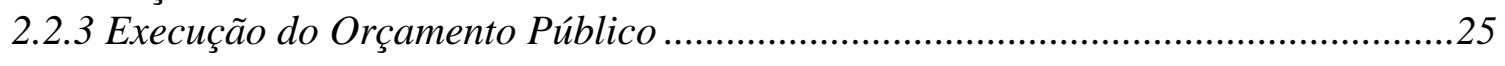

2.3 DESPESA PÚBLICA .....................................................................................................28

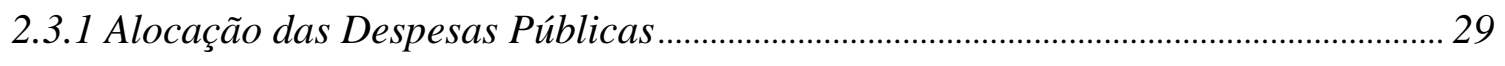

3 ESTUdos EMPÍRICOS..........................................................................................................31

4 MÉTODOS E TÉCNICAS DE PESQUISA.......................................................................34

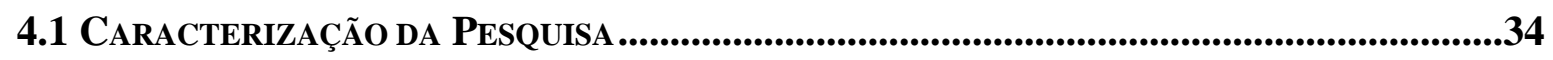

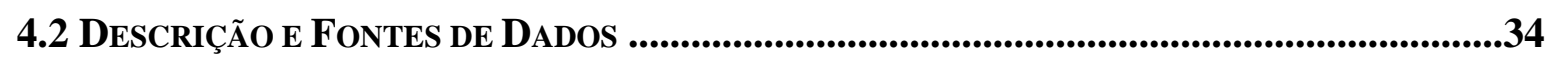

4.3 VARIÁVEIS DEPENDENTES....................................................................................34

4.4 VARIÁVEIS de ConTROLE DEMOGRÁFICO ......................................................................35

4.5 Variáveis de Controle Político............................................................................35

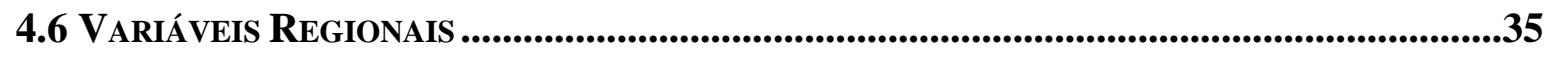

4.7 TRATAMENTO DOS DAdOS........................................................................................36

4.8 APRESENTAÇÃo E ANÁlISE dOS DAdOS ......................................................................................37

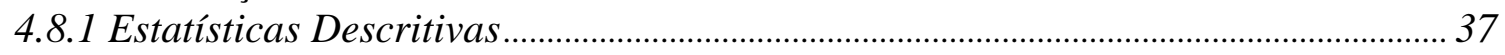

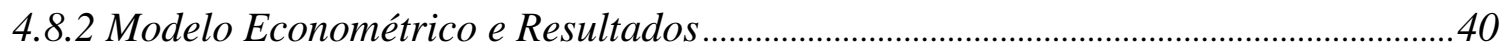

5 CONCLUSÃO

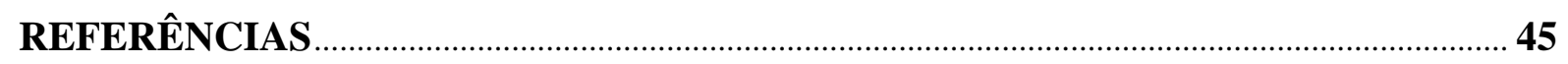




\section{INTRODUÇÃO}

A economia, desde sua origem, sempre esteve ligada às questões políticas. O sentido desta relação, na maioria das vezes, é o da política não só como influência, mas como determinante dos resultados da economia. Segundo Drazen e Eslava (2000), a economia política enfatiza o uso técnico e formal das ferramentas da moderna análise econômica.

Diante da questão das relações entre economia e política, algumas pesquisas têm tido como objeto o comportamento dos mercados, enquanto outras têm focado a própria interação entre a motivação econômica e a decisão política. Dentre estas, se destaca o tópico referente aos ciclos políticos.

O estudo sobre ciclos políticos eleitorais tem ganhado importância na literatura econômica. No modelo tradicional de ciclos políticos, o incumbente e o eleitor interagem baseados nas preferências dos eleitores (por gastos, setores, provisão de bens públicos ou mesmo um controle mais rígido e conservador das contas públicas). Os políticos, cientes de tais preferências, expandem os gastos em uma determinada área ou aumentam o superávit de sua própria unidade da federação com o objetivo de conseguir vantagens eleitorais em comparação aos seus rivais.

A teoria dos ciclos políticos aborda a interação política com os sistemas econômicos, ao passo que os políticos se preocupam com a obtenção e manutenção do poder, despertando interesse não só de pesquisadores do tema como também de públicos distintos.

Acredita-se que é possível obter uma explicação adequada para os ciclos políticos observando que muitos políticos, nos períodos pré-eleitorais, criam condições favoráveis na economia, esperando que o eleitor lhes dê a devida retribuição por isso, a reeleição, ou o partido que o apoia, ainda que imediatamente após a eleição, procure fazer a economia retomar seu estado anterior, ou até mesmo a uma situação pior.

Para Fialho (1999), a possibilidade de ocorrência de ciclos políticos é importante por diversas razões. Todavia, talvez a mais relevante delas seja a de que as não considerações dos motivos político-eleitorais do governo na análise macroeconômica podem levar a diagnósticos equivocados que implicam, por sua vez, em imprecisões e erros nas previsões da trajetória futura dos eventos econômicos.

Durante décadas, diversos estudos têm enfatizado a influência que a política parece exercer sobre o desempenho da atividade econômica, de uma forma geral, e sobre os instrumentos e resultados da política macroeconômica, em particular. Porém, a possibilidade 
de conexão entre calendário eleitoral e ciclo econômico com foco nas despesas públicas, ainda é pouco abordada.

Dessa forma, essa pesquisa procura oferecer uma explicação adicional ou alternativa para as flutuações econômicas, fundamentalmente por tomarem como relevante a participação dos agentes políticos ou do governo na determinação da trajetória na economia.

O panorama político influencia a trajetória das variáveis econômicas, uma vez que relaciona medidas anteriores ao período eleitoral e medidas pós-eleição. No entanto, o ciclo político pode ter um padrão muito mais complexo, envolvendo transferências governamentais, despesas públicas, fases do mandato, orientações ideológicas dos governantes e estruturas partidárias.

Em termos teóricos usam-se diferentes comportamentos para definir dois tipos de ciclo político. Os modelos de ciclo político podem ser classificados de acordo com o comportamento do político em partidário ou oportunista. A escola de análise relacionada à existência de incentivos oportunistas pode ser caracterizada por considerar o pressuposto de que agentes, independentemente de ideologia partidária, visam implícita e fundamentalmente manter-se no poder. Esta corrente analítica pode ser dividida em duas abordagens, uma considerando expectativas adaptativas, Nordhaus (1975) e outra considerando expectativas racionais Rogoff (1990), mas ambas procurando justificar a existência de ciclos em função do calendário eleitoral.

Paralelamente ao desenvolvimento da abordagem teórica que analisa elementos de ordem oportunista na determinação de ciclos econômicos, a segunda vertente teórica procura enfatizar as diferenças ideológicas ou partidárias, e a possibilidade de este fator afetar o comportamento da economia. As referências são os trabalhos de Hibbs (1977), considerando o pressuposto de expectativas adaptativas e Alesina (1987), pressupondo expectativas racionais. De acordo com esta abordagem, os partidos políticos apresentariam preferências diferentes em relação à conduta de suas respectivas políticas econômicas e, assim, existiria um comportamento distinto da economia em função de uma consistência ideológica por parte dos partidos políticos, uma vez estando no poder.

As eleições ainda são o meio pelo qual se cria a responsabilidade do político com o eleitorado. Elas permitem ao eleitor escolher o candidato que lhe parece mais competente ou mais se aproxima de suas preferências e posições ideológicas. A performance reflete não somente características do político (como ideologia e competência) ou ocorrências externas, mas também a falta de comportamento oportunista do político, a ameaça de não ser reeleito acaba servindo para motivá-lo. 
Por isso, além dos aspectos do foco para a pesquisa, de acordo com Blanco (2000), é preciso que se percebam alguns aspectos que ressaltam a importância dos níveis subnacionais de governo. Neste sentido, a participação destes níveis inferiores de governo, na receita pública disponível no país, a importância dos Estados e Municípios e a participação das despesas públicas, já seriam motivos suficientes para salientar a importância da política em nível subnacional no país.

Centrar o estudo nas despesas públicas dos Estados brasileiros tende a facilitar a identificação de evidências de ciclo político na utilização das mesmas, do padrão de magnitude dessas despesas ao longo do ciclo eleitoral, bem como daquelas onde essas manipulações seriam mais evidentes.

$\mathrm{O}$ foco desta pesquisa está restrito à vertente dos ciclos políticos que, de maneira mais específica, explora a presença de ciclos eleitorais nas variáveis de política econômica e seus impactos sobre as variáveis macroeconômicas. Diante do exposto a presente pesquisa se concentra na análise das despesas públicas, procurando-se investigar a presença de componentes cíclicos cuja trajetória temporal coincida com os calendários eleitorais - isto é, a presença de uma tendência cíclica de aceleração das despesas públicas no período préeleitoral e sua desaceleração pós-eleitoral. Em função disso, busca-se nesta pesquisa, verificar a existência dos impactos dos ciclos políticos nas despesas públicas dos estados brasileiros entre 1995 e 2013, considerando magnitude e tipo de despesa.

A presente pesquisa foi organizada em quatro seções, sendo primeiramente a introdução apresentada, na qual foram definidas a justificativa e o objetivo da pesquisa. $\mathrm{Na}$ segunda seção, apresenta-se a fundamentação teórica, subdividida em títulos contendo aspectos sobre Modelos de Ciclos Políticos, Orçamento Público e Despesa Pública. A terceira seção trata de estudos empíricos. A quarta seção trata dos aspectos metodológicos do trabalho, em que a pesquisa é caracterizada e os procedimentos para coleta, análise e tratamento de dados são explicados. Na última seção, são apresentadas as conclusões obtidas no estudo. 


\section{REFERENCIAL TEÓRICO}

\subsection{Modelos de Ciclos Políticos}

Fialho (1999) afirma que a busca de evidências históricas e estatísticas que sinalizam uma conexão entre calendário eleitoral e flutuações econômicas procuram oferecer uma explicação adicional para tais flutuações. Segundo a autora, este foco tomado pela teoria de ciclos políticos difere de outros estudos sobre flutuações econômicas de curto prazo fundamentalmente por tomarem como endógena e relevante a participação dos agentes políticos (ou do governo) na determinação da trajetória da economia.

De acordo com Borsani (2003) tal debate apoia-se tanto na teoria econômica da democracia elaborada por Downs (1957), na qual os partidos políticos são entendidos como agentes maximizadores de preferências eleitorais na competição de obter ou manter o poder, quanto na perspectiva shumpeteriana de classificação dos formuladores de política econômica como empresários maximizadores de votos.

Vários estudos formais sobre os ciclos políticos foram elaborados e contestados em suas premissas básicas, levando a uma subdivisão destes estudos de acordo com as hipóteses sobre o comportamento dos agentes econômicos envolvidos no processo eleitoral: eleitores e governantes. Temos então, pela dicotomia de hipóteses embutida tanto no comportamento do eleitorado quanto no dos policymakers e seus partidos políticos.

São quatro vertentes dos modelos de ciclos políticos. Sobre o comportamento dos policymakers, há uma divisão entre aqueles que acreditam que os governantes fazem suas escolhas de política econômica por puro oportunismo político, e os que afirmam que partidos de direita e esquerda tendem a adotar políticas econômicas opostas por questões ideológicas. Já as hipóteses sobre o eleitorado dizem respeito à forma com que estes agentes eleitorais formulam suas expectativas, sendo de forma adaptativa pela teoria dos ciclos políticoeconômicos de Nordhaus e partidários de Hibbs, e de forma racional pela teoria dos ciclos político-orçamentários de Rogoff e Sibert e partidário racional de Alesina.

Os modelos de ciclos político-econômicos tomam como pressuposto a crítica de Downs (1957), sobre a benevolência dos formuladores de política econômica e afirmam que estes policymakers desviam a condução da política econômica do "socialmente ótimo" com o objetivo de alcançar sucesso nas urnas. De acordo com estes modelos, a relação entre conjuntura econômica e calendário eleitoral pode ser percebida pela existência de flutuações 
econômicas de curto prazo politicamente induzidas, nas quais a trajetória das variáveis macroeconômicas encontra pontos de inflexão justamente nos períodos pré-eleitorais.

Simultaneamente ao crescimento dos estudos teóricos sobre ciclos políticos - advindos da refutação dos pressupostos básicos contidos no modelo oportunista tradicional de Nordhaus sobre o comportamento dos envolvidos no processo eleitoral, governantes e eleitorados -, vários trabalhos empíricos surgiram com o objetivo de encontrar evidências que sinalizassem a ocorrência de correlação entre a conjuntura econômica e o calendário eleitoral.

\subsubsection{Modelos Partidários com Expectativa Adaptativa}

Esta abordagem surge com o trabalho de Hibbs (1977), considerando que os partidos políticos querem se manter no poder para implementar as suas ideologias através de políticas públicas que visem beneficiar aquele determinado grupo de eleitores que o apoiou.

A teoria partidária introduz a noção básica de que as flutuações cíclicas da economia, motivadas por fatores políticos, assumem tendências distintas quando se leva em conta as características e metas específicas dos partidos políticos.

Desta forma, o modelo proposto por Hibbs (1977) considera que, se cada partido tenta beneficiar o grupo de interesse ao qual pertence, os partidos de direita, que geralmente estão relacionados à classe economicamente favorecida, teriam maior aversão à inflação e, portanto, buscariam reduzir suas taxas e consequentemente, aumentariam o desemprego, enquanto os partidos de esquerda, geralmente ligados às classes economicamente desfavorecidas, teriam uma maior preocupação com o combate ao desemprego.

No contexto da hierarquia das classes sociais, os partidos apresentam bases eleitorais ou suportes políticos diversos. Partidos progressistas se identificariam mais com classes sociais hierarquicamente mais baixas que, pelas suas características sócioeconômicas, são mais sensíveis a problemas relacionados ao desemprego e menos sensíveis aos relacionados à inflação. Por outro lado, os partidos conservadores, baseados eleitoralmente em grupos ou classes sociais mais elevadas, dão maior ênfase à inflação. Esta distinção do suporte político dos partidos acabaria por gerar metas de política macroeconômica distintas, consistentes com os interesses de suas bases eleitorais.

A classificação da preferência dos partidos em relação às metas de política econômica indica que governos progressistas ou socialistas parecem ser mais avessos ao desemprego e menos à inflação. 
Governos conservadores demonstram mais preocupação com as expectativas inflacionárias e tendem, portanto, a adotar políticas econômicas mais restritivas como a forma de reduzir a inflação, demonstrando maior cautela em relação à expansão da demanda agregada e redução na taxa de desemprego.

\subsubsection{Modelos Oportunistas com Expectativa Adaptativa}

A literatura dos Ciclos Políticos Eleitorais teve início com Nordhaus em 1975, com a publicação do artigo The Political Business Cycle, no qual o autor apresenta um modelo em que os eleitores são, sistematicamente, enganados por políticos oportunistas, que manipulam a política monetária de modo a provocar um crescimento econômico de curto prazo no período próximo às eleições e, assim, aumentarem suas chances de reeleição. Após as eleições e com o intuito de combater a inflação gerada pela política monetária anterior, o político eleito adota uma política monetária mais apertada para provocar uma redução na taxa de crescimento. Os impactos sobre o crescimento econômico, portanto, são temporários.

O modelo desenvolvido por Nordhaus (1975) está embasado na ideia, defendida por Downs (1957), de que os políticos são oportunistas tendo como motivação a maximização de votos para sua permanência no poder. Para tanto policymakers estimulam a demanda agregada antes das eleições, por meio de uma política monetária expansionista, acelerando o crescimento econômico e reduzindo o desemprego, com o intuito de garantir sua própria reeleição ou de seu partido.

Devido às políticas emergenciais e oportunistas pré-eleitorais, o período posterior ao escrutínio inicia-se com altas taxas de inflação e retração econômica. Logo, o governo tende a adotar medidas políticas fiscais e monetárias restritivas para combater a inflação, contraindo a atividade econômica e aumentando os níveis de desemprego.

\subsubsection{Modelos Oportunistas com Expectativa Racional}

Elaborada a partir de estudos de Rogoff e Sibert (1988), o modelo oportunista com expectativa racional leva em conta o comportamento do eleitor que possui mais conhecimento e embasamento analítico de medidas puramente eleitorais.

Dessa forma, o modelo oportunista anteriormente proposto por Nordhaus (1975) é modificado, ao incluir as expectativas racionais nos estudos de Rogoff e Sibert (1988). Esta última análise de modelo de ciclo politico, que inclui o eleitor mais consciente, acaba 
impondo certa disciplina aos gastos públicos, contemplando o eleitor que faz predileção ao governo competente, que, geralmente, utiliza-se de menos receita para apresentar resultados em sua gestão.

Por outro lado, o modelo de Rogoff (1990), enfatiza a composição das despesas públicas em vez das receitas. Os governantes sinalizam a sua competência aumentando as despesas públicas em bens e serviços e em transferências e diminuindo o investimento público, uma vez que este último apenas se torna visível em períodos posteriores à eleição.

\subsubsection{Modelos Partidários com Expectativa Racional}

Hibbs (1977) propõe em seu estudo de modelos partidários que, dentre diversos aspectos, os políticos tendem a privilegiar aqueles que os elegeram, a fim de permanecerem no poder. Dessa forma, os objetivos de modelo de gestão são flexionados quanto às variáveis econômicas e os interesses do eleitor potencial.

Assim, pode-se aferir que os modelos partidário e oportunista se relacionam de acordo com o comportamento do eleitor e questões econômicas, tais como desemprego e inflação. O modelo partidário de Hibbs (1997) implica em diferenças na combinação inflação versus desemprego escolhida pelos diferentes partidos políticos ou uma combinação deles. Partidos de esquerda tendem a adotar políticas inflacionárias. Por outro lado, os partidos de direita, políticas recessivas.

Os eleitores agem de acordo com sua preferência ideológica do partido ou coligação no poder. Os partidos de direita, conservadores, tendem a privilegiar a classe mais abastada da sociedade, principalmente classes média e média alta, além de favorecer a liberdade de mercado e defender direitos e poderes sociais contra a intervenção do Estado. Por outro lado os partidos de esquerda, que favorecem o controle estatal da economia e a interferência ativa do governo em todos os setores sociais.

Alesina (1998), a fim de testar os modelos dos ciclos políticos, realizou um estudo para os Estados Unidos e para 18 países da OCDE. Os dados obtidos revelaram não haver sinais evidentes de que a economia cresça mais rápida que a média, e que a taxa de desemprego seja mais baixa que a média, durante o período pré-eleitoral. Não foi observado também aumento da inflação após as eleições. Resultado semelhante foi identificado para os países da OCDE. 
De maneira geral, foi constatado que há pouca evidência de manipulações eleitoreiras em períodos pré-eleitorais em ambos os estudos. Ou seja, maior crescimento econômico e menor desemprego em períodos pré-eleitorais.

Tabela 1 - Evolução das Teorias de Ciclos Políticos

\section{QUADRO COMPARATIVO DOS MODELOS DE CICLOS POLÍTICOS}

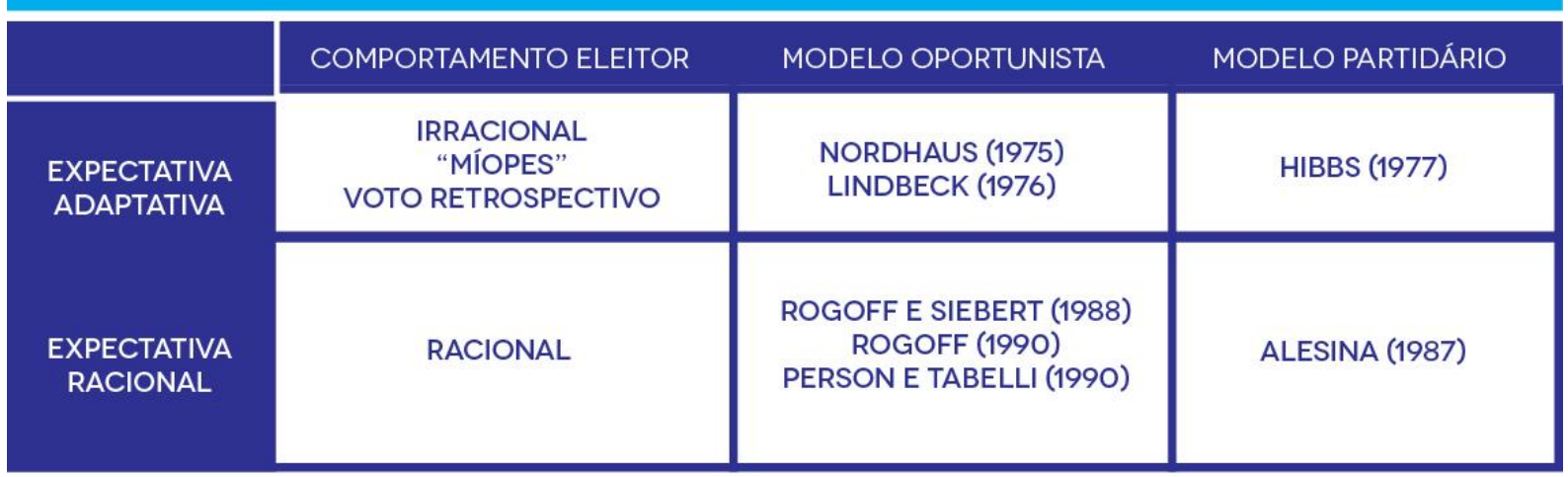

Fonte: Alesina, Roubini, Cohen, 1997. Com adaptações

\subsection{O Orçamento Público}

Nas sociedades organizadas o sistema jurídico está estruturado para que os cidadãos, os destinatários das ações estatais, não sejam surpreendidos por medidas intempestivas tomadas pelos governantes. Este fato justifica a existência do orçamento público, cujas origens se confundem com o surgimento do Estado de Direito.

A concepção de que os gastos dos governantes devem ser previamente autorizados vem desde o ano de 1217, com a edição da Magna Charta Libertatum do Reino Unido. A trajetória histórica do orçamento público remonta a uma época em que o rei ou imperador era o próprio Estado. Não havia, então, distinção entre as finanças particulares do soberano e as do Governo.

Com o crescimento do Estado, tornou-se necessário proceder a uma melhor organização de suas receitas e despesas, nascendo assim o orçamento público. O seu aprimoramento o transformou em uma ferramenta indispensável para as instituições governamentais. Sua história foi marcada por árduas lutas políticas que o tornaram um instrumento necessário ao equilíbrio dos interesses antagônicos em volta do poder.

Para Pellini (2006), desde o surgimento do Estado Moderno, os homens foram criando mecanismos para o controle da ação dos seus governantes. Inicialmente a preocupação residia 
na cobrança de impostos. Em 1215, os barões ingleses vencem João Sem-Terra e obrigam-no a assinar a Carta Magna, na qual estabelece o embrião do orçamento, através do princípio de que nenhum tributo seria levantado sem o consentimento do Conselho do Reino.

Com o passar do tempo e a expansão das atividades estatais, surgiu a preocupação com a boa aplicação dos recursos públicos e o orçamento deixa de ser apenas lei de impostos para transformar-se em plano de ação governamental. Atualmente são complexos e sofisticados instrumentos institucionais de controle da ação governamental.

Para Baleeiro (2008), o orçamento é considerado o ato pelo qual o Poder Legislativo prevê e autoriza ao Poder Executivo, por certo período, as despesas destinadas ao funcionamento dos serviços públicos e outros fins adotados pela política econômica ou geral do país, assim como a arrecadação das receitas já criadas em lei.

O orçamento é utilizado como um meio de controle e um instrumento de gestão, expressa a vida financeira de um Município, Estado ou País, revelando suas transações e movimentações ao longo de um exercício financeiro. É utilizado como uma ferramenta de transparência, pois é votado em sessões abertas que contam com a participação da população que pode votar em projetos que gerem benefícios para a sociedade. Com a participação da sociedade, a elaboração da lei do orçamento torna-se mais clara e transparente, sendo possível para a população acompanhar o andamento dos projetos aprovados por eles e auxiliar na fiscalização dos gastos públicos.

No caso brasileiro, a experiência tem demonstrado, ao longo dos últimos anos, que, longe de caracterizar um plano de ação do governo corroborado pela sociedade, o orçamento nem sempre é tratado com a relevância que possui, sendo visto muitas vezes como acessório apenas para cumprir as exigências legais. Destaca-se que o orçamento não gera recursos, sua atuação se caracteriza na redistribuição das riquezas disponíveis na sociedade e arrecadadas pelo Estado por meio dos tributos.

Dessa forma, além de representar um instrumento de caráter da vontade popular, justificada pela atuação do Poder Legislativo nas fases de aprovação e controle, o orçamento deve contribuir com a redução das desigualdades da sociedade, uma vez que consiste em poderoso instrumento de planejamento das ações governamentais, possibilitando a distribuição de riquezas, sendo necessário, para isso, que a sua elaboração e execução sejam realizadas com a responsabilidade e a competência necessárias à correta gestão em prol do interesse público. 


\subsubsection{Evolução Histórica}

Os países que mais se destacaram pelo desenvolvimento da técnica orçamentária foram a Inglaterra, a França, os Estados Unidos e o Brasil. Porém como cita Baleeiro (2008), o ponto de partida nasce nos primórdios da Idade Média, quando as instituições feudais fracionavam o poder real, ou imperial, e confundiam receitas privadas do domínio do príncipe com receitas autoritárias.

Para Wilges (1995), a prática orçamentária teve sua origem há vários séculos, quando as obrigações tributárias impostas pelos monarcas se tornaram impossíveis de serem suportadas.

Por outro lado, Araújo e Arruda (2006) acreditam que a origem do orçamento público ocorreu no século XIII, mais precisamente em 1215, na Inglaterra, remontando ao momento em que a Carta Magna foi imposta ao Rei João Sem-Terra pelos senhores feudais, com o objetivo de limitar seus poderes sobre a arrecadação e a forma de realização dos gastos.

Desta maneira, temos que cabe a Inglaterra a primazia na prática orçamentária, cujo início se deu com a promulgação da Carta Magna e se desenvolveu com a evolução do governo parlamentarista do país.

\subsubsection{Orçamento no Brasil}

A tributação da metrópole portuguesa na colônia brasileira ocasionou graves descontentamentos. A Inconfidência Mineira (1785 - 1789) foi um desses movimentos. O estopim do movimento foi a emanação de tributos portugueses na colônia. Portugal queria receber todos os impostos atrasados (fato conhecido como Derrama) e causou profunda inquietação social que culminou com o citado movimento e a morte de Joaquim José da Silva Xavier - Tiradentes (1746-1792).

Por outro lado, o rei de Portugal, D. João VI, pressionado por acontecimentos na Europa, mais precisamente no tocante ao Imperador Francês, Napoleão, que forçava Portugal a fechar seus portos para a Inglaterra abandonou sua terra natal, fortemente escoltado por navios ingleses, e se estabeleceu no Brasil. Sua chegada à colônia promoveu a organização das finanças e o disciplinamento dos tributos aduaneiros. O regime de contabilidade pública, o Erário Público (Tesouro), o Conselho Real da Fazenda e três contadorias reais foram criados em 1808. 
De acordo com Giacomoni (2007), com a vinda do rei D. João VI, o Brasil iniciou um processo de organização de suas finanças. A abertura dos portos trouxe a necessidade de maior disciplinamento na cobrança dos tributos aduaneiros. Em 1808, foram criados o Erário Público (tesouro) e o regime de contabilidade.

Estudiosos apontam, que o primeiro orçamento brasileiro teria sido, então, aquele aprovado pelo Decreto Legislativo de 1830 que fixava a despesa e orçava a receita das antigas províncias para o exercício de 01.07.1831 a 30.06.1832.

A Lei Magna brasileira de 1824 afirmava em seu texto que ao Executivo competia à elaboração da proposta orçamentária e à Assembleia Geral (Câmara dos Deputados e Senado) a aprovação da Lei Orçamentária. À Câmara dos Deputados competia ainda à iniciativa das leis sobre impostos.

Com a Constituição de 1891, que seguiu à Proclamação da República, houve importante alteração na distribuição das competências em relação ao orçamento. A elaboração desse passou a ser função do Congresso Nacional, assim como a tomada de contas do Poder Executivo. Com essa nova sistemática, coube à Câmara dos Deputados a iniciativa de elaboração do orçamento público brasileiro.

Visando auxiliar o Congresso Nacional em sua missão institucional de controle externo da contas públicas, a Constituição Federal instituiu o Tribunal de Contas da União.

$\mathrm{Na}$ República, as antigas províncias transformam-se em Estados regidos por constituições próprias, o que lhes assegurou grande autonomia. Igualmente, a primeira constituição republicana que tratou de estender essa autonomia aos Municípios. (GIACOMONI, 2007).

Com a aprovação do Código de Contabilidade da União pelo Congresso Nacional, em 1922, ordenaram-se os procedimentos orçamentários, financeiros, patrimoniais, contábeis etc. Quanto à iniciativa da lei orçamentária, o código legalizou o que já estava acontecendo, informalmente, na gestão federal. O Executivo fornecia ao Legislativo todos os elementos para que esse exercitasse sua atribuição de iniciar a feitura da lei orçamentária.

Em 16 de julho de 1934, é outorgada uma nova Constituição Brasileira, e a autonomia dos Estados e o federalismo desenhados pela Carta de 1891 cederam lugar à centralização da maior parte das funções públicas na área federal. A iniciativa da elaboração da proposta orçamentária volta a ser do presidente da República, cabendo ao Congresso Nacional a votação da proposta e o julgamento das contas do presidente, contanto para tal com o auxílio do Tribunal de Contas da União. 
Crises políticas jogaram o País num regime fortemente autoritário, o Estado Novo, gerador de nova Constituição decretada em 1937. A elaboração orçamentária foi tratada com destaque, merecendo um capítulo especial com seis artigos. Segundo essas disposições, a proposta orçamentária seria elaborada por um departamento administrativo a ser criado junto à Presidência da República e votada pela Câmara dos Deputados e pelo Conselho Federal. A verdade é que essas duas câmaras legislativas nunca foram instaladas e o orçamento federal foi sempre elaborado e decretado pelo chefe do poder Executivo. (VIANA, 1996).

Em 1939, o regime estado-novo liquidou com o que restava de autonomia dos Estados e Municípios ao transferir ao presidente da República a prerrogativa de nomear os governadores estaduais (interventores) e a esses a nomeação dos prefeitos. (GIACOMONI, 2007).

Com o restabelecimento da democracia no país, foi promulgada uma nova Constituição, em 1946. Ela consagrava certos princípios, como o da unidade, o da universalidade, o da exclusividade e o da especialização, princípios esses até hoje orientadores do nosso orçamento. O orçamento passou a funcionar nos moldes da Constituição de 1934, sendo que o Poder Executivo elaborava o projeto de lei orçamentária e a discussão e votação acontecia no Poder Legislativo. Através de emendas, os legisladores também participavam da elaboração do orçamento e o papel do Tribunal de Contas foi evidenciado de forma mais precisa.

A Lei $n^{\circ} 4320$, ainda vigente, produto resultante de inúmeras colaborações, que estatuiu normas gerais de direito financeiro para elaboração e controle dos orçamentos e balanços da União, dos Estados, dos Municípios e do Distrito Federal, padronizou o modelo orçamentário para os três níveis de governo, facilitando os procedimentos contábeis, financeiros e orçamentários nos diversos níveis de gestão governamental. Essa Lei que foi aprovada com força de lei ordinária em sua época passou a ter força de Lei Complementar, em diversos de seus artigos, por determinação expressa da Constituição Federal de 1988.

Em 24 de janeiro de 1967 foi publicada a sexta constituição brasileira. A grande novidade residiu na retirada de prerrogativas do Legislativo quanto à iniciativa de leis ou emendas que criem ou aumentem despesas, inclusive emendas ao projeto de lei do orçamento. O texto dessa constituição mostra grande preocupação com a "segurança nacional", ostentando tendência de centralização político-administrativo na União e de ampliação dos poderes do Presidente da República.

O Decreto-Lei 200, de 25 de fevereiro de 1967, vigente também até os dias atuais, disciplina a organização e a reforma administrativa da União. O Planejamento foi definido, pela primeira vez em nosso ordenamento jurídico, como princípio fundamental e norteador das atividades da administração federal, tendo como instrumento básico o orçamento- 
programa anual e os Programas Gerais, Setoriais, Regionais (todos de duração Plurianual), o Plano Geral de Governo e a Programação Financeira de Desembolso.

A EC n ${ }^{\circ} 1 / 1969$, embora formalmente seja uma emenda à Constituição de 1967, é considerada por muitos constitucionalistas verdadeiramente uma nova Constituição. A emenda serviu como mecanismo de outorga, ou seja, imposição de novas disposições constitucionais sem consentimento do parlamento. Uma peculiaridade histórica dessa constituição é que ela se denominava "Constituição da República Federativa do Brasil", a de 1967 era, simplesmente, "Constituição do Brasil".

A constituição de 1969 alterou diversos artigos da carta de 1967, mas manteve os dispositivos sobre orçamento, inclusive o que limita a capacidade de iniciativa do Legislativo em leis que gerem despesas e em emendas ao orçamento quando de sua discussão. Em alguns aspectos ela aperfeiçoou o processo de elaboração da lei orçamentária, a fiscalização financeira e orçamentária dos municípios, modificou o sistema tributário, entre outros assuntos.

Nos anos oitenta iniciaram as pressões no campo político com vistas ao fim do regime autoritário e à abertura institucional. No biênio 1982/1983, com o agravamento da crise econômica, ficou evidente a fragilidade da base política do governo, que assistiu às campanhas de forte conteúdo popular, como a das "diretas já" para Presidente da República, e a convocação de uma Assembleia Nacional Constituinte.

Em 1988, o país recebeu sua atual constituição. O tema orçamento foi fortemente discutido entre os constituintes, pois era visto como símbolo dos privilégios perdidos durante o período autoritário. Novos conceitos e regras foram introduzidos, bem com a confirmação de princípios e normas já consagrados.

Entre as inovações, podemos citar a exigência de, anualmente, o Executivo encaminhar ao Legislativo, o projeto de lei de diretrizes orçamentárias com o objetivo de orientar a elaboração da lei orçamentária.

\subsubsection{Execução do Orçamento Público}

O final da década de 90 foi marcado, no Brasil, por uma profunda transformação no cenário econômico e político do país, com a implementação de condutas que buscavam a adequação do nosso país às novas exigências do cenário internacional. Para que o Brasil incorporasse as noções de competitividade e desenvolvimento, era necessário que o setor

público desse também sua quota nesta busca, e que as atividades financeiras dos 
administradores públicos se adequassem ao novo modelo de Estado, com o controle mais racional e probo do Orçamento Público.

A preocupação com o descontrole fiscal das Unidades Federativas, que cria obstáculos à manutenção da estabilidade econômica, ensejou a aprovação em 04 de maio de 2000 da Lei de Responsabilidade Fiscal com a finalidade de estabelecer critérios, condições e limites à gestão orçamentária, financeira e patrimonial, implantando novos mecanismos de controle das contas públicas.

A Lei de Responsabilidade Fiscal, busca justamente o equilíbrio entre receitas e despesas e a estagnação da dívida pública, impondo um rígido controle ao gasto público e ao administrador que o faz, eis que denominada Lei de Responsabilidade Fiscal.

Com a LRF, há necessidade de se cuidar da execução orçamentária para que as metas planejadas possam ser alcançadas. Uma das inovações trazidas pela LRF é a necessidade de se fazer uma programação financeira, que é a execução orçamentária e o cumprimento das metas, que deve ser realizada em até 30 dias após a publicação dos orçamentos, nos termos que dispuser a LDO inciso I do art. $4^{\circ}$ alínea c, do poder executivo estabelecerá a programação financeira, nos termos do artigo $8^{\circ}$ da LRF, consiste na execução do cronograma mensal de desembolso.

Com esse mecanismo a LRF determina a fixação das metas bimestrais. Se a arrecadação de receitas vier a comprometer as metas fiscais é necessária a limitação dos gastos públicos na forma prevista na LDO, conforme determina o artigo $9^{\circ}$ da LRF.

O sistema de planejamento público brasileiro encontra-se previsto no artigo 165 da Constituição Federal de 1988, segundo a qual a proposição das leis orçamentárias são de competência exclusiva do Poder Executivo e devem levar em conta o Plano Plurianual (PPA), a Lei de Diretrizes Orçamentárias (LDO) e a Lei Orçamentária Anual (LOA).

O Plano Plurianual (PPA) é uma lei que abrange os respectivos poderes da União, nos Estados, no Distrito Federal e nos Municípios; será elaborada no primeiro ano do mandato do Executivo e terá vigência de quatro anos. De acordo com o parágrafo $1^{\circ}$ do artigo 165 da Constituição Federal, a lei que instituir o plano plurianual estabelecerá, de forma regionalizada, as diretrizes, objetivos e metas da administração pública federal para as despesas de capital e outras dela decorrentes e para as relativas aos programas de duração continuada.

Com PPA, o governo organiza e declara seu plano de ação. No entanto, é com a execução do orçamento que se tem a efetiva realização das políticas públicas. É comum na etapa de execução do orçamento surgirem necessidades imprevistas e ajustes para a aplicação 
dos recursos públicos. Isto pode ser por meio de adequações, tais como ordenar as ações do governo para alcançar o objetivo e metas fixada para um período de 4 anos. Cada objetivo está associado a metas que fornecerão parâmetros para as realizações esperadas naquele período, e quando necessário, devem ser revistas as metas previstas, tendo em vista a nova realidade que se apresenta.

Para uma gestão bem planejada o governo tem que seguir as leis estabelecidas tais como a LDO, que busca garantir o cumprimento dos resultados fiscais e obter maior controle sobre os gastos da administração pública, e também para manter o equilíbrio entre as receitas e despesas no momento da execução orçamentária.

A Lei de Diretrizes Orçamentárias (LDO) é a lei anterior à lei orçamentária, que compreenderá as metas e prioridades da administração pública federal, incluindo as despesas de capital para o exercício financeiro subseqüente, orientará a elaboração da lei orçamentária anual, disporá sobre as alterações na legislação tributária e estabelecerá a política de aplicação das agências financeiras oficiais e de fomento.

Com a LDO fica mais fácil cumprir as instruções orçamentárias e também fica mais objetivo atender as necessidades, pois os programas e projetos a serem realizados podem ser priorizados. Também é preciso haver preocupação com volume de despesas, pois a LRF estipula alguns parâmetros para que o gestor assuma despesas de caráter continuado.

A Lei Orçamentária Anual (LOA) disciplina todos os programas e ações do governo federal no exercício, sendo neste instituto que são estimados os recursos a serem arrecadados (receitas) bem como fixado o montante das despesas a serem executadas para atender as necessidades da população e permitir o desenvolvimento das atividades da máquina administrativa.

A Lei Federal 4.320/64 cita que a execução de programação orçamentária é uma tarefa que, depois de ser aprovado, o plano de trabalho e os limites financeiros para a sua execução dentro dos recursos que o governo é autorizado para arrecadar, as despesas serão fixadas e o executivo deve estabelecer limites para trabalhar no quadro das cotas trimestrais para cada unidade orçamentária. Assim, a programação das despesas, depois de serem aprovadas a cotas, o executivo estará delegando as unidades para os respectivos e responsabilidades da movimentação dos créditos orçamentários, conforme a programação destas a serem executadas. Com as adequações feitas durante o ano, a programação anual de trabalho, o governo fixando as cotas na medida do possível vai trazer o equilíbrio entre a receita arrecada e despesa realizada, de modo a reduzir ao mínimo, eventuais insuficiências de tesouraria. $\mathrm{O}$ governo deve executar as cotas bimestrais com estimativa da receita que deve ser com critério 
e objetividade, e permitir a execução que foi aprovada no orçamento, evitando os déficits dos cofres públicos, os quais obrigam a administração a recorrer aos créditos operacionais. Para evitar déficit público é preciso que se atualize anualmente as bases de cálculo das receitas e deve-se estabelecer os gastos com base na programação trimestral conforme artigos 47 e 50 da Lei 4.320/64.

Ao final de cada bimestre, se a realização da receita não comportar o cumprimento das metas de resultado primário ou nominal, os gestores são necessários nos trinta dias subseqüentes a limitação de empenhos e movimentação financeira, conforme citado nos critérios fixados pela LDO.

O poder executivo, no final dos meses de maio, setembro e fevereiro, demonstrará e avaliará o cumprimento das metas fiscais de cada quadrimestre, nas audiências públicas na comissão, conforme cita a Lei complementar $n^{\circ} 101 / 2000$.

\subsection{Despesa Pública}

Para Timbó e Piscitelli (2009), despesa pública caracteriza um dispêndio de recursos do patrimônio público, representado essencialmente por uma saída de recursos financeiros, imediata - com redução de disponibilidades - ou mediata com reconhecimento dessa obrigação.

De acordo com Albuquerque, Medeiros e Feijó (2013), conceitua-se como despesa pública o conjunto de dispêndios do Estado ou de outra pessoa de Direito Público a qualquer título, a fim de saldar gastos fixados na lei do orçamento ou em lei especial, visando à realização e ao funcionamento dos serviços públicos. Nesse sentido, a despesa é parte do orçamento, ou seja, aquela em que se encontram classificadas todas as autorizações para gastos com as várias atribuições e funções governamentais.

As despesas públicas podem ser classificadas sob vários enfoques, sendo os mais expressivos e consagrados pela doutrina os seguintes:

a) quanto à natureza;

b) quanto à categoria econômica;

c) quanto à competência institucional;

d) quanto à afetação patrimonial;

e) quanto à regularidade.

Por outro lado, a classificação da despesa sob o enfoque administrativo-legal possui fundamental importância no processo de execução ao classificar em três grandes grupos: os 
órgãos e unidades orçamentárias; as funções, as subfunções e os programas de governo, indicando os gastos fixados no orçamento com as respectivas fontes de recursos, dando origem ao programa de trabalho do governo, propiciando informações úteis ao processo de tomada de decisões e evidenciando a sua política econômica e financeira.

As classificações orçamentárias permitem, portanto, a visualização da despesa sob diferentes enfoques ou abordagens, conforme o ângulo em que se pretende analisar. Cada uma delas possui uma função ou finalidade específica e um objetivo original, que justifica sua criação.

A classificação funcional constitui-se em condição essencial para a implantação do orçamento-programa. Pois essa classificação identifica as grandes áreas de atuação do Estado, fixando-se objetivos para cada uma delas e, por conseqüência, as ações que se pretende desenvolver para o alcance desses propósitos.

A classificação atual está estruturada em dois níveis de agregação: funções e subfunções, às quais estão vinculados os programas, que possuem em sua estrutura projetos, atividades e operações especiais, reagrupados de acordo com o critério de afinidade ou tipicidade, possibilitando, dessa maneira, analisar de forma mais precisa as prioridades do Governo nas suas diversas áreas de atuação.

A classificação funcional, de acordo com a legislação em vigor, foi introduzida nos orçamentos federal e estadual nos exercício de 2000, e nos Municípios, em 2002.

Nesta pesquisa foram analisadas as funções apresentadas a seguir:

a) Defesa Nacional e Segurança Pública - inclui os órgãos encarregados do planejamento e demais atividades ligadas à segurança pública e às instituições do poder judiciário estadual;

b) Saúde e Saneamento - inclui as ações de promoção, proteção, recuperação e reabilitação, desenvolvidas com o objetivo da melhoria do nível de saúde da população; c) Educação, Cultura, Desporto e Lazer - inclui as ações voltadas à formação intelectual, moral, cívica e profissional do homem, assim como sua habilitação para uma participação eficaz no processo de desenvolvimento econômico e social. Estão inclusas nesta função, políticas destinadas ao incentivo e à promoção de programas culturais e desportivos.

\subsubsection{Alocação das Despesas Públicas}

O comportamento das despesas públicas está relacionado ao aparato legal existente, que, de uma maneira geral, explicita a partir de um contexto de limitação fiscal, que tipo de despesa pública deve ser privilegiada. 
Neste sentido, a legislação existente privilegia os gastos com saúde e educação estabelecendo percentuais de gastos obrigatórios vinculados com a receita.

No que se refere à educação, a Constituição Federal de 1988, impõe que a União vincule $18 \%$ dos recursos oriundos da receita de impostos federais; que os Estados vinculem $25 \%$ das receitas de impostos que arrecadam como também daquelas receitas que lhes são transferidas; que os municípios vinculem $25 \%$ das receitas resultantes de impostos, incluindo os recursos provenientes de transferências.

A contribuição social do salário-educação também tem como destino o financiamento da educação através do Fundo Nacional de Desenvolvimento da Educação - FNDE. Também o Fundo de Manutenção e Desenvolvimento do Ensino Fundamental e Valorização do Magistério - FUNDEF, criado pela Emenda Constitucional n ${ }^{\circ} 4$, de 12 de setembro de 1996, que obrigou os entes federados, a partir de 1998, a alocarem 60\% dos recursos para a educação no ensino fundamental, constitui um marco legal para financiamento da ação governamental em educação.

Em relação à saúde, o Ato das Disposições Constitucionais Transitórias da Constituição Federal prevê, após a Emenda Constitucional n² 29, de 13 de setembro de 2000, um patamar mínimo inicial, para 2000, de 7\% das receitas municipais e estaduais a serem aplicadas em saúde e um acréscimo de 5\% sobre o montante empenhado pelo Ministério da Saúde em 1999. Nos anos seguintes, até 2004, os percentuais previstos para estados e municípios deveriam elevar-se até atingir $12 \%$ das receitas estaduais e $15 \%$ das receitas municipais, enquanto a participação da União seria corrigida pela variação nominal do Produto Interno Bruto - PIB. (FAVERET, 2003) 


\section{ESTUDOS EMPÍRICOS}

Há um crescente número de discussões e estudos sobre a influência dos ciclos políticos nas decisões relativas à condução da política econômica, sobretudo no que tange as despesas públicas e transferências governamentais.

Fialho (1999), pode ser considerado um dos primeiros estudos em que tal relação é analisada de maneira formal, embora esta seja apenas uma das várias referências que procuram argumentar sobre a relevância de tal interação. Em seu estudo, analisou a validade da hipótese de ciclos políticos como uma explicação para a política macroeconômica brasileira. Foi estimado um modelo de séries temporais usando dados para o período de 19531995. A análise revelou que o período eleitoral afeta, de uma maneira positiva, a política monetária e a taxa de crescimento do Produto Interno Bruto real. Outros resultados não apontaram efeitos significativos, do ciclo eleitoral sobre as taxas de desemprego e de inflação.

Sousa (2014), identificou em seu estudo quais as influências das alterações ocorridas nas estruturas de composição dos gastos públicos dos governos estaduais do Brasil sobre o desenvolvimento humano local. A pesquisa foi conduzida através da análise dos gastos dos governos estaduais e dos indicadores de desenvolvimento humano local, no período pósconstitucional, entre os anos de 1988 e 2011.

Os gastos públicos dos estados foram categorizados por sua natureza em Índices de Gastos (IG), composto do gasto social (s), mínimo (m) e econômico (e). O desenvolvimento humano foi mensurado através da criação de um Índice de Desenvolvimento Humano (DH) composto por indicadores de saúde, educação e renda. Para verificar a natureza das relações entre as variáveis, foi concebido um modelo teórico de caráter contábil-social, de modo a identificar a influência das taxas de crescimento dos gastos públicos sobre o desenvolvimento humano no âmbito dos estados.

O modelo foi estimado com a utilização dos IG e DH dos 26 estados do Brasil, através da técnica estatística do Modelo de Crescimento Latente (MCL). O período de mensuração para o MCL incorporou cinco ciclos de gestão dos estados, de 1992 a 2008 e, considerando as evidências quanto a influência do ciclo eleitoral na natureza do gasto, obtidas através de Análise Fatorial e Clusters, foram utilizados como momento de mensuração das variáveis o segundo ano do período de gestão dos governos estaduais, sendo as variáveis do modelo medidas para os anos de 1992, 1996, 2000, 2004 e 2008.

Por meio da análise segmentada dos parâmetros estimados pelo modelo teórico contábil-social para cada estrutura de gasto público: índice de gasto social (IGs), índice de 
gasto econômico (IGe) e índice de gasto mínimo (IGm), foi possível evidenciar a influência de fatores institucionais, prioritariamente da regulação centralizadas sobre as políticas públicas sociais, na formação e evolução das estruturas de composição dos gastos dos governos estaduais do Brasil no período pós-constitucional.

O exame das relações estimadas pelo modelo operacional demonstrou, como esperado, que apenas o crescimento dos gastos nas políticas sociais (IGs), como educação, saúde, habitação e assistência social, teve efeito estatisticamente significativo sobre a taxa de crescimento do desenvolvimento humano; entretanto, esta influência não foi considerada de grande magnitude.

Dentre os demais preditores, o mais significativo foi o valor médio inicial do gasto mínimo (IGm), o que denota a influência direta da adoção da Lei de Responsabilidade Fiscal sobre a melhoria das condições de DH. As alterações na estrutura do gasto econômico (IGe) foram mínimas no período, não sendo sua taxa de crescimento significante no teste do modelo. Entretanto, seu valor médio inicial apontou efeito positivo e significativo sobre a taxa de crescimento do $\mathrm{DH}$, em valor bem próximo ao obtido pela estrutura de gasto em políticas sociais (IGs), o que reforça a influência desta categoria de gasto para propiciar condições necessárias à disseminação e aproveitamento dos benefícios do desenvolvimento humano.

Os resultados, de modo geral, confirmam a tese do estudo, que as alterações nas estruturas dos gastos públicos promovidas pela Constituição Federal de 1988 tiveram influência positiva sobre o desenvolvimento humano, entretanto, a magnitude desta influência é considerada modesta, frente às alterações na estrutura de composição dos gastos.

Silva (2014), analisou o comportamento dos gastos públicos dos municípios mineiros e a relação de suas flutuações com o calendário eleitoral, a fim de detectar comportamentos cíclicos na condução da política físcal. Foram analisados 853 municípios do estado de Minas Gerais, divididos de acordo com a classificação por mesorregiões geográficas, para o período de 2000-2008. Utilizando abordagem econométrica de dados em painel, foram testadas as despesas orçamentárias, os gastos sociais e gastos econômicos a fim de detectar possíveis manipulações de caráter eleitoral executadas pelos governantes. Os resultados sugerem que, para os municípios do estado de Minas Gerais, o calendário eleitoral exerce influência estatisticamente significativa sobre o comportamento das despesas públicas.

Nakaguma (2010), investigou as causas determinantes da existência de ciclos eleitorais na política fiscal dos estados brasileiros e, em que medida, os eleitores são capazes de captar as sinalizações de competência emitidas pelos governantes e identificar e punir políticos oportunistas. Para tanto, propôs uma metodologia para decompor os ciclos políticos, 
procurando identificar as parcelas devidas ao oportunismo e à atividade sinalizadora dos governantes. O resultado principal é o de que o eleitorado recompensa a parcela oportunista dos ciclos, tanto nas receitas quanto nas despesas, embora este efeito tenha diminuído ao longo das eleições.

Por fim, um trabalho que aborda de forma específica o caso dos municípios brasileiros é Sakurai (2007), no qual é analisado o comportamento fiscal das unidades locais paulistas entre 1989 e 2001. Os resultados do estudo sugerem que para a despesa orçamentária e para a despesa corrente são observados impulsos de gastos nos anos eleitorais de 1992 e 1996, embora tal comportamento não seja observado no caso da despesa de pessoal, transferências correntes e despesa de investimento.

No que diz respeito ao teste para os partidos políticos, os resultados obtidos demonstram algumas distinções particulares, como por exemplo, o fato de o PT ser o partido que menos gasta em transferências correntes; as maiores despesas agregadas do PFL têm como origem seus maiores gastos em investimentos públicos; os maiores gastos agregados observados para o PTB e para o PPB / PDS têm como origem seus maiores gastos em despesas de pessoal e, finalmente, o PSDB também se destaca por despender maiores recursos em despesas de pessoal. Por fim, os resultados também sugerem que o alinhamento partidário entre os prefeitos e o governador estadual não influencia o comportamento das variáveis supracitadas, dentro do período analisado. 


\section{MÉTODOS E TÉCNICAS DE PESQUISA}

\subsection{Caracterização da Pesquisa}

Segundo Richardson (1999), a abordagem quantitativa de pesquisa desenvolve-se por meio do emprego da quantificação desde a coleta das informações até a análise final por meio de técnicas estatísticas. Esta pesquisa caracteriza-se, portanto como predominantemente quantitativa, pois está focada na mensuração de fenômenos.

$\mathrm{Na}$ investigação que será apresentada, objetivou-se analisar a relação existente entre despesas públicas e ciclos políticos, classificando-se como pesquisa descritiva, a qual tem como principal objetivo descrever características de determinada população ou fenômeno ou estabelecimento de relações entre as variáveis.

\subsection{Descrição e Fontes de Dados}

Os dados que foram utilizados na pesquisa podem ser divididos em 4 grupos. A primeira parte corresponde às variáveis dependentes que são as variáveis de despesas públicas. Este conjunto de variáveis é utilizado para verificar se essas despesas são potencializadas em anos eleitorais.

No segundo grupo serão apresentados os controles demográficos. No terceiro será apresentada a metodologia utilizada para a construção das variáveis políticas. Por fim, no quarto grupo, será abordada a metodologia de construção da variável que pretende captar o efeito das despesas públicas das regiões brasileiras.

\subsection{Variáveis Dependentes}

A fonte de dados das variáveis dependentes utilizadas foi obtida através do site do Tesouro Nacional por meio do Sistema de Coleta de Dados Contábeis (SISTN), mantido em parceria com a Caixa Econômica Federal, com o objetivo de consolidação das Contas Nacionais. A periodicidade dos dados é anual e foram utilizados 18 anos para a construção da base de dados, de 1995 a 2013.

Com relação às despesas públicas, foram analisadas as seguintes despesas: segurança pública, saúde e educação, por serem consideradas típicas da atuação dos governos estaduais. 
As despesas com segurança pública foram agrupadas com as despesas de defesa nacional. A despesa referente à saúde foi agrupada em saneamento, assim como as despesas referentes a educação foram agrupadas com as de cultura, lazer e as com desporto.

\subsection{Variáveis de Controle Demográfico}

As variáveis de controle consideradas nesta pesquisa seguem a literatura econômica e foram coletadas nos sites IPEADATA e IBGE. São elas: percentual de analfabetos, população residente, proporção de mulheres, renda domiciliar per capita e coeficiente de Gini.

\subsection{Variáveis de Controle Político}

Foram criadas variáveis dummies com valor igual a um para o ano eleitoral, para identificar se o governador é candidato à reeleição, valor igual a um para os anos em que a LRF passou a vigorar. Além de variáveis que identificam se o alinhamento ideológico entre o partido do presidente e o do governador do estado são os mesmos. Com relação à última variável, estas tentam captar a influência política que pode gerar algum possível beneficiamento com relação às verbas existentes entre estas estâncias.

A variável de ideologia foi mantida tal como utilizada em Botelho (2002) ${ }^{1}$, em que assume valores iguais a 1 para partidos ditos de esquerda e 0 para partidos de direita.

Os resultados das eleições estaduais, as coligações e a compatibilização dos partidos dos governadores de estado com o partido do presidente foram coletados no site do Tribunal Superior Eleitoral (TSE).

\subsection{Variáveis Regionais}

A variável que foi utilizada para captar o efeito das despesas públicas dos Estados brasileiros em questão foi construída com base na média das despesas para as respectivas regiões.

\footnotetext{
${ }^{1}$ Foram considerados os seguintes partidos de esquerda: PT, PCB, PCdoB, PPS, PSB, PV, PDT, PSTU.
} 


\subsection{Tratamento dos Dados}

Para analisar o efeito dos ciclos políticos nas despesas públicas foi utilizada a metodologia de dados em painel por possuir uma larga escala de aceitação graças às vantagens que esta possui em relação às técnicas baseadas em cross-section (estudo de uma ou mais variáveis no tempo) e séries temporais (observações feitas sequencialmente ao longo do tempo).

Além de possibilitar a análise a partir de um maior conjunto informativo e de trabalhar com um nível de colinearidade desprezível entre as variáveis explicativas, é possível controlar a heterogeneidade individual.

De acordo com Lakatos e Marconi (2004), a descrição da análise de dados em painel é uma técnica que possibilita estudar uma população em dois ou mais momentos sucessivos, com a finalidade de verificar a influência de um ou vários fatores de natureza semelhante, sendo que as pesquisas feitas com a utilização da mesma oferecem maior vantagem ao número de variáveis e dados, os quais podem ser processados com maior objetividade e riqueza de detalhes.

De acordo com Hsiao (1986), os modelos de dados em painel oferecem algumas vantagens em relação aos modelos de séries temporais tais como: a) controlam a desigualdade presente nos fenômenos; b) permitem o uso de mais observações, aumentando o número de graus de liberdade; c) são capazes de mensurar efeitos que não são possíveis de serem detectados por meio de séries temporais; d) possibilidade de construir e testar modelos mais complexos; e) possibilidade de trabalhar melhor certas variáveis e modelos em nível micro.

O painel pode ser dividido em painel balanceado e painel não balanceado. Nesta pesquisa foi utilizado o painel balanceado em que cada estado possui o mesmo número de observações temporais.

O modelo de dados em painel pode ser aplicado por meio de dois métodos de estimação - de efeito fixo e de efeito aleatório. No método de efeitos fixos, cada indivíduo tem características próprias que podem ou não influenciar as variáveis explicativas, por outro lado, o método de efeitos aleatórios pressupõe que o comportamento específico dos indivíduos e períodos de tempo é desconhecido, não podendo ser observado, nem medido.

Para verificar qual método de estimação seria o mais adequado para esta pesquisa, foi utilizado o teste de Hausman, que avalia a consistência de um estimador comparado a outro estimador alternativo, ou seja, método de efeito fixo ou aleatório. 
Por fim, para a tabulação dos dados, foi utilizado o programa Microsoft Excel versão 2010, enquanto os procedimentos econométricos e análise empírica foram realizados através do Stata 13.0.

\subsection{Apresentação e Análise dos Dados}

\subsubsection{Estatísticas Descritivas}

Os dados da Tabela 1 referem-se às estatísticas descritivas das variáveis envolvidas na pesquisa, obtidas para o período de 1995 a 2013, considerando todos os Estados contemplados no estudo.

As estatísticas descritivas compreendem a apresentação das informações básicas das variáveis e dados envolvidos na pesquisa. As principais informações dizem respeito às médias e desvio-padrão.

Tabela 2 - Estatísticas Descritivas: Estados Brasileiros

\begin{tabular}{lrr}
\hline \hline \multicolumn{1}{c}{ Variáveis } & \multicolumn{1}{c}{ Média } & Desvio Padrão \\
\hline \hline Despesa - Defesa Nacional e Segurança Pública & $\mathrm{R} \$ 761.761 .261,76$ & $\mathrm{R} \$ 1.429 .192 .493,31$ \\
Despesa - Saúde e Saneamento & $\mathrm{R} \$ 1.361 .723 .533,43$ & $\mathrm{R} \$ 6.897 .309 .104,67$ \\
Despesa - Educação e Cultura & $\mathrm{R} \$ 2.452 .688 .791,14$ & $\mathrm{R} \$ 21.240 .540 .934,75$ \\
Analfabetos - 15 anos ou mais & 14,05 & 8,16 \\
Renda Domiciliar Per Capita & $\mathrm{R} \$ 702,93$ & $\mathrm{R} \$ 292,21$ \\
População Residente Total & $6.527 .734,78$ & $7.784 .355,948$ \\
Coeficiente de Gini & 0,5537 & 0,0422 \\
Proporção Mulheres & 0,5139 & 0,1215 \\
Mesmo partido & 0,1851 & 0,3888 \\
Partido Esquerda & 0,3368 & 0,4750 \\
Mesma coligação & 0,3509 & 0,4785 \\
Reeleito & 0,3809 & 0,4903 \\
Reeleito governador & 0,2768 & 0,4545 \\
Ano de eleição & 0,2345 & 0,3975 \\
LRF & 0,7142 & 0,4334 \\
\hline \hline
\end{tabular}

Fonte: Elaboração própria a partir de dados da pesquisa 
A despesa referente à Defesa Nacional e Segurança Pública média foi de R\$ 761.761.261,76 (setecentos e sessenta e um milhões, setecentos e sessenta e um mil, duzentos e sessenta e um reais e setenta e seis centavos), desvio-padrão de $\mathrm{R} \$ 1.429 .192 .493,31$ (um bilhão, quatrocentos e vinte e nove milhões, cento e noventa e dois mil, quatrocentos e noventa e três reais e trinta e um centavos), o que mostra a elevada heterogeneidade dos dados, devido ao número de Estados e diferentes estágios de desenvolvimento social que se encontram, considerando-se a extensão e diversidade dos Estados.

Em relação às Despesas de Saúde e Saneamento, a média foi de R \$ 1.361.723.533,43 (um bilhão, trezentos e sessenta e um milhões, setecentos e vinte e três mil, quinhentos e trinta e três reais e quarenta e três centavos), com desvio-padrão de $\mathrm{R} \$$ 6.897.309.104,67 (seis bilhões, oitocentos e noventa e sete milhões, trezentos e nove mil, cento e quatro reais e sessenta e sete centavos).

A média de Despesas referentes à Educação e à Cultura foi de R $2.452 .688 .791,14$ (dois bilhões, quatrocentos e cinqüenta e dois milhões, seiscentos e oitenta e oito mil, setecentos e noventa e um reais e catorze centavos), com desvio-padrão de R\$ 21.240.540.934,75 (vinte e um bilhões, duzentos e quarenta milhões, quinhentos e quarenta mil, novecentos e trinta e quatro reais e setenta e cinco centavos).

As Despesas referentes à Saúde e Educação, indicam, no mesmo sentido, que as Despesas com Defesa Nacional e Segurança Pública, uma alta heterogeneidade dos dados, decorrente em parte das diferenças apresentadas pelos diversos Estados brasileiros. O desviopadrão denota uma diferença de aplicação nas funções acima destacadas consideradas como bastante acima da média, o que decorre, em parte, além das diferenças estaduais, as demandas sociais diferenciadas.

Em relação à Renda Domiciliar per capita, a média é de R \$ 702,93 (setecentos e dois reais e noventa e três centavos) por domicílio nos estados considerados, sendo que o desviopadrão de $\mathrm{R}$ \$ 292,21 corrobora com a existência de heterogeneidade econômica existente entre as cidades dos estados pesquisados, decorrente da extensão do mesmo e das diferenças regionais acentuadas.

Segundo os dados disponibilizados pela Secretaria do Tesouro Nacional, a evolução das despesas com educação, saúde e segurança pública pode ser observada nos gráficos 1,2 e 3 . 


\section{SEGURANÇA E DEFESA NACIONAL}

despesa (em bilhões)

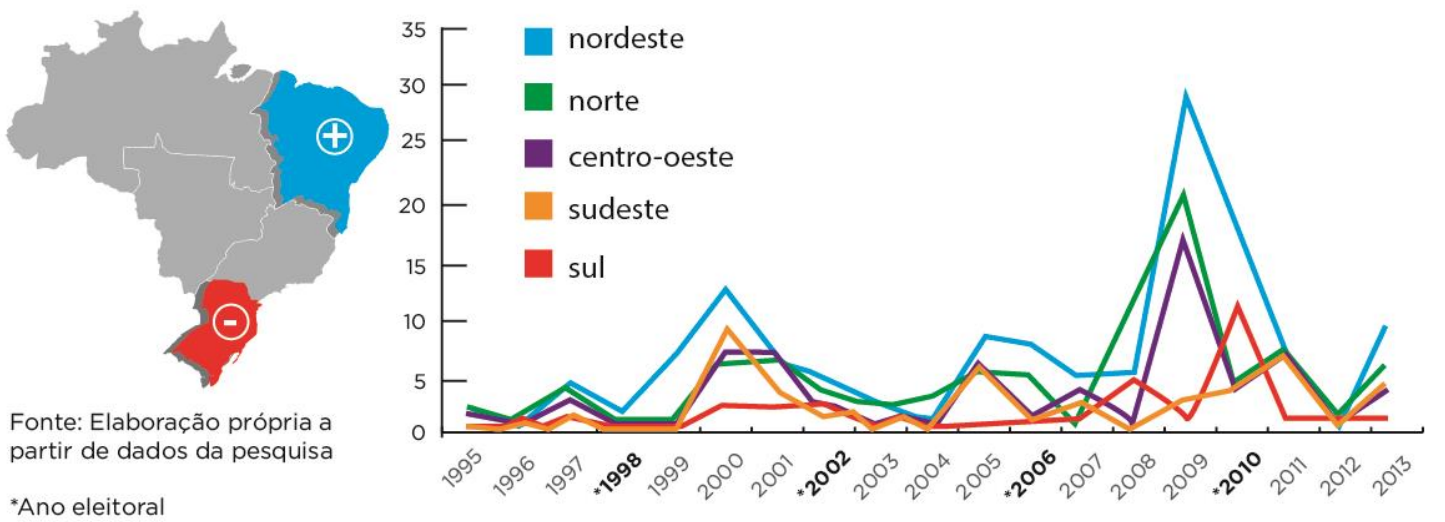

\section{SAÚDE E SANEAMENTO}

despesa (em bilhões)

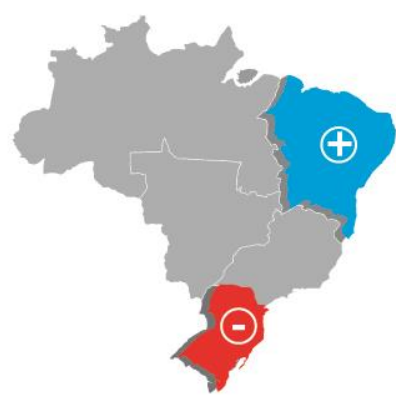

Fonte: Elaboração própria a partir de dados da pesquisa

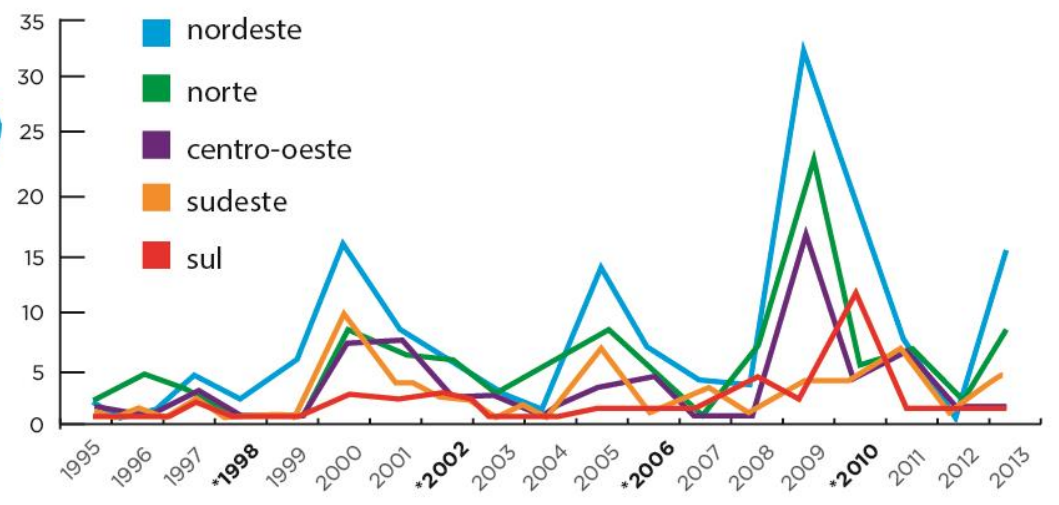

${ }^{*}$ Ano eleitoral

\section{EDUCAÇÃO, CULTURA, DESPORTO E LAZER}

despesa (em bilhões)

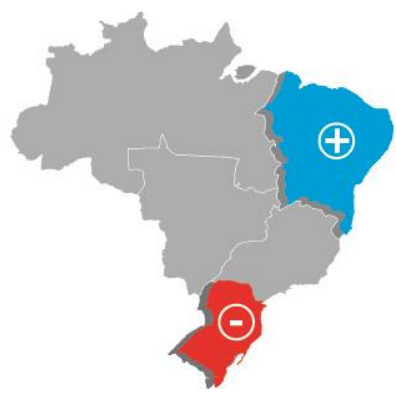

Fonte: Elaboração própria a partir de dados da pesquisa

${ }^{*}$ Ano eleitoral

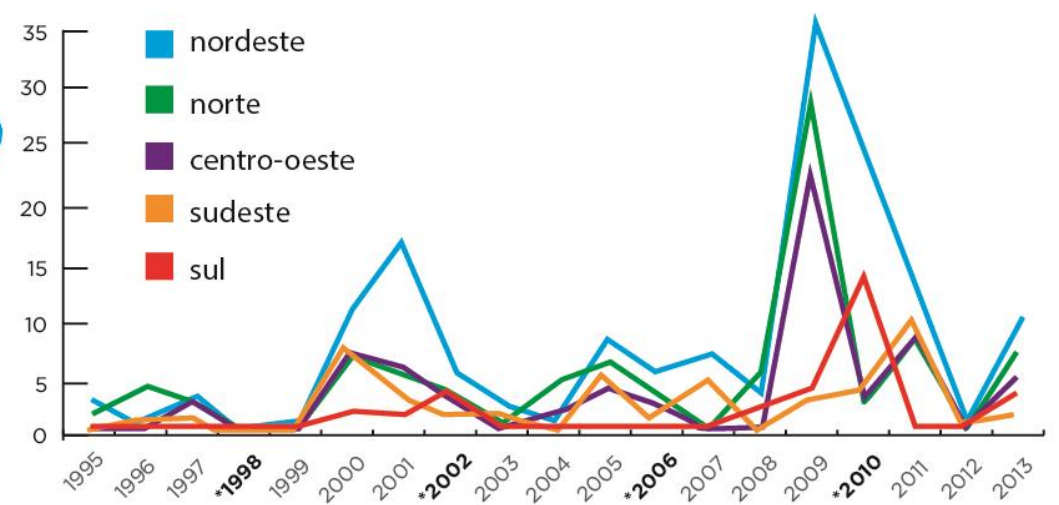


As estimações das despesas de Educação, Saúde e Segurança Pública sugerem um comportamento cíclico de expansão das despesas no período pré-eleitoral, ou seja, política fiscal expansiva. Por outro lado, no período pós-eleitoral, há uma contração ou ajuste das despesas, ou seja, política fiscal restritiva.

Com relação às despesas totais, observa-se que as despesas nos setores tendem a aumentar 2 anos após o período eleitoral. Esta constatação deve-se a dois fatos prováveis: à necessidade de realizar ajustes fiscais após as eleições, ou seja, de que os governos precisam de tempo para tomar posse de fato e tomar decisões com relação à despesa, ou a probabilidade de reeleição, que revela uma maneira de se promover um melhor controle das despesas, evitando a aplicação de recursos públicos em despesas que não sejam prioridade da população

Os resultados para as despesas sugerem que a existência de ciclo político possui o auge no período pré-eleitoral. Sob o prisma das teorias de ciclos orçamentários, este comportamento poderia ser atribuído ao fato de os investimentos em saúde, educação e segurança pública demandarem maior lapso de tempo para serem concluídos e, assim, para que o eleitorado possa usufruir seus benefícios.

É um comportamento típico do governante brasileiro a aceleração de obras em período pré-eleitoral, com intuito de demonstrar para sociedade resultados tangíveis de sua administração.

Partindo desta análise preliminar dos dados, a próxima seção abordará os modelos econométricos analisados na pesquisa, e suas implicações para os diversos tipos de gastos analisados, procurando discutir a existência de ciclos políticos eleitorais nos estados brasileiros.

\subsubsection{Modelo Econométrico e Resultados}

Nesta seção serão apresentados os principais resultados dos modelos estimados para as principais variáveis analisadas, conforme apresentado na seção anterior.

$\mathrm{Na}$ estimação, foram considerados tanto modelos de efeitos fixos quanto efeitos aleatórios. Entretanto, após testes de Hausman, conclui-se pela adequação dos modelos de efeitos fixos para o caso das despesas de educação, cultura, lazer e desporto (modelos 1) e efeitos aleatórios para os casos de saúde e saneamento e defesa nacional e segurança pública (modelos 2 e 3 ).

Observou-se um bom poder de predição, avaliado por níveis de $\mathrm{R}^{2}$ relativamente altos 0.8475 (modelo 1), 0.5346 (modelo 2) e 0.7837 (modelo 3). 
O teste para avaliação da significância geral do modelo obtido foi feito com base no coeficiente de determinação $\mathrm{R}^{2}$.

A verificação de significância dos coeficientes de regressão permite que seja assegurado que os "coeficientes estimados sejam de fato diferentes de zero" (HAIR, 2005).

Entre as variáveis estatisticamente significativas estão o coeficiente de Gini (modelo 2), ln de população (modelos 1, 2, e 3), reeleição do governador (modelo 1), reeleição do presidente (modelos 1 e 3 ) e a constante (modelos 1 e 3 ).

Em relação ao coeficiente de Gini, ele se mostrou estatisticamente significativo somente no modelo 2, referente às despesas de saúde e saneamento, com sinal positivo, indicando que um maior nível de desigualdade - maior índice de Gini - leva a um maior gasto em saúde e saneamento. Isso pode estar relacionado a uma tentativa de amenizar a desigualdade social no país via maiores gastos.

Em relação à população, o sinal do coeficiente é positivo nos quatro modelos para os quais ele se mostrou estatisticamente significativo, indicando que quanto maior a população, maior será o dispêndio com as despesas sociais aqui pesquisadas.

Em relação às variáveis políticas, observa-se que enquanto a reeleição do governador tende a reduzir gastos com educação, cultura, lazer e desporto (modelo 1 - sinal negativo), a reeleição do presidente tende a aumentar esses gastos e também os gastos com defesa nacional e segurança pública (modelos 1 e 3), indicando impacto da política nacional nos gastos estaduais.

Os resultados são apresentados na tabela a seguir: 
Tabela 3 - Resultados dos Modelos Econométricos

\begin{tabular}{|c|c|c|c|}
\hline Variável & $\begin{array}{l}\text { Modelo 1 } \\
\text { Ln Despesa } \\
\text { Educação } \\
\text { (EF) } \\
\end{array}$ & $\begin{array}{c}\text { Modelo } 2 \\
\text { Ln Saúde } \\
\text { (EA) }\end{array}$ & $\begin{array}{c}\text { Modelo } 3 \\
\text { Ln Defesa } \\
\text { (EA) }\end{array}$ \\
\hline $\begin{array}{l}\text { Ln Renda Per } \\
\text { Capita }\end{array}$ & 0.5367 & 0.3323 & 0.8353 \\
\hline $\begin{array}{l}\text { Percentual de } \\
\text { Analfabetos }\end{array}$ & -0.0185 & -0.0360 & -0.0131 \\
\hline Coeficiente de Gini & -1.2086 & $5.2239 * *$ & 0.3467 \\
\hline Ln População & $2.2981 * *$ & $0.5664 * * *$ & $1.0511 * * *$ \\
\hline Partido de Esquerda & -0.1007 & 0.2270 & 0.1098 \\
\hline $\begin{array}{l}\text { Mesma Coligação } \\
\text { (Presidente e } \\
\text { Governador) }\end{array}$ & -0.0319 & 0.0297 & -0.0156 \\
\hline $\begin{array}{l}\text { Mesmo Partido } \\
\text { (Presidente e } \\
\text { Governador) }\end{array}$ & -0.0989 & 0.2677 & -0.0446 \\
\hline $\begin{array}{l}\text { Reeleição } \\
\text { Governador }\end{array}$ & $-0.1446 *$ & -0.2172 & 0.1943 \\
\hline $\begin{array}{l}\text { Reeleição } \\
\text { Presidente }\end{array}$ & $.30346 * * *$ & 0.2068 & $0.2810 * *$ \\
\hline Ano Eleitoral & -0.0114 & 0.0003 & -0.1932 \\
\hline Constante & $-24.1164 *$ & -1.2212 & $-9.4886 * *$ \\
\hline $\mathrm{R}^{2}$ & 0.8475 & 0.5346 & 0.7837 \\
\hline
\end{tabular}

Fonte: Elaboração própria a partir de dados da pesquisa.

Notas: ***, ** e * representam nível de significância, respectivamente, de $1 \%, 5 \%$ e $10 \%$. As regressões em negrito representam os dados que apresentaram melhor ajuste. 


\section{CONCLUSÃO}

A pesquisa propôs constatar evidências de que a situação eleitoral influi nas despesas públicas, em particular nos setores da educação, saúde e segurança pública. Para tanto, foram utilizados os 26 estados brasileiros e o Distrito Federal a fim de testar o modelo em painel para os anos de 1995 a 2013.

Os ciclos políticos nas variáveis da despesa pública, sugerem que o padrão da despesa pública é influenciado por considerações eleitoreiras. Neste sentido, os resultados desta pesquisa insinuam que os governantes candidatos à reeleição possuiriam incentivos ainda maiores para manipulação das despesas públicas, direcionando-as para áreas em que seus efeitos sejam mais explicitamente percebidos pelo eleitorado.

A competência de um político só pode ser atestada de fato pelo eleitor com certa defasagem de tempo. Assim, os governantes sinalizam maior competência no período préeleitoral, normalmente através de políticas visíveis como: aumento de despesas, maior provisão de bens públicos, redução de impostos e aumento de transferências.

A probabilidade da reeleição revela uma maneira de se promover um melhor controle das despesas, evitando a aplicação de recursos públicos em despesas que não sejam prioridade da população, bem como exigindo dos governantes uma maior responsabilidade fiscal, o que os leva a gerir o erário com mais eficiência. Na tentativa de se reeleger, os governantes preveem ações voltadas à infraestrutura e expansão das políticas sociais investindo em financiamento de construções, ampliações e reformas.

A análise das despesas públicas revelou a forma e a intensidade do ciclo eleitoral em cada setor. Estes resultados corroboram a idéia de que os eleitores valorizam distintamente os gastos em cada área, e que, conscientes deste fato, os políticos atuam oportunamente, concentrando os gastos nos setores mais rentáveis em termos de votos.

De acordo com os resultados auferidos, verifica-se que o aumento significativo das despesas públicas sugere a criação e manutenção dos planos e programas de governo, com intuito de prover, ampliar, reestruturar e dar continuidade à assistência a população.

Espera-se que a amplitude dos ciclos políticos diminua ao longo do tempo, fato que poderá ser atribuído ao amadurecimento do eleitorado, que, com a experiência que adquire ao longo de eleições sucessivas, possa ser capaz de identificar e punir políticos oportunistas, reduzindo, assim, a intensidade dos ciclos. 
Conclui-se que a política fiscal na esfera federal e estadual reflete um comportamento cíclico, orientado para interesses eleitorais. A diferença nos padrões cíclicos apresentados ajuda a entender melhor a maneira como o orçamento é programado.

Espera-se que os resultados desta pesquisa possam servir de contribuição no processo de alocação das despesas referente a políticas sociais, mediante conjugação das legislações orçamentárias e eleitoral que sejam promotoras de uma programação de longo prazo voltada para o desenvolvimento e progresso econômico-social do país.

Por fim, uma extensão empírica para esta pesquisa consiste em trabalhar com dados municipais, o que aumentaria os graus de liberdade do estudo econométrico, na tentativa de reduzir a disparidade revelada na pesquisa com dados estaduais. Além disso, pode-se também trabalhar com outras variáveis e, ainda utilizar um estimador mais adequado à realidade e voltado para este tipo de pesquisa. 


\section{REFERÊNCIAS}

ALBUQUERQUE, Claudiano; FEIJÓ, Paulo Henrique; MEDEIROS, Márcio. Gestão de Finanças Públicas: Fundamentos e Práticas de Planejamento, Orçamento e Administração Financeira com Responsabilidade Fiscal. Brasília: Gestão Pública Editora e Treinamentos Sociedade e Ltda - EPP, 2013.

ALESINA, A. Macroeconomic Policy in a Two Party System as a Repeated Game. Quaterly Journal of Economics, v.102, p.651-78, 1987.

ALESINA, A.; ROUBINI, N. Political cycles in OECD economies. The Review of Economic Studies, v.59, 1992.

ALESINA, A. SACHS, J. Political parties and the business cycle in the United States. Journal os Money, Credit and Banking, v. 20, 1988.

ARAÚJO, Inaldo; ARRUDA, Daniel. Contabilidade Pública da Teoria à Prática. São Paulo: Saraiva, 2006.

ARAÚJO, Jevuks M.; FILHO, Paulo.A.M. Ciclos político-econômicos: uma análise do comportamento dos gastos públicos nos estados brasileiros no período de 1995 a 2008. Disponível em: $\quad$ http://www.anpec.org.br/encontro2010/inscricao/arquivos/000f137e0a2e5c8515bca4e4fbb5791d6cb.pdf

BALEEIRO, Aliomar. Uma introdução à Ciência das Finanças. Rio de Janeiro: Forense, 2008.

BLANCO, Cossio. F. Política Fiscal nos Estados Brasileiros. Disponível em: http://www.ipea.gov.br/portal/images/stories/PDFs/TDs/td_0404.pdf

BORSANI, Hugo. Eleições e economia: instituições políticas e resultados macroeconômicos na América Latina (1979-1998). Belo Horizonte: Editora UFMG; Rio de Janeiro: IUPERJ, 2003.

BRASIL. Constituição Federal (1998). Constituição da República Federativa do Brasil: 1998. Disponível em: http://www.planalto.gov.br/ccivil_03/constituicao/constituicao.htm.

Decreto Lei 200 de 25 de fevereiro de 1967. Disponível em: https://www.planalto.gov.br/ccivil_03/decreto-lei/Del0200.htm 
. Lei Complementar (2000). Lei Complementar n⿳ 101, de 4 de maio de 2000.

Disponível em: http://www.planalto.gov.br/ccivil_03/leis/LCP/Lcp101.htm.

Lei 4.320 (1964). Lei 4.320, de 17 de março de 1964. Disponível em: http://www.planalto.gov.br/ccivil_03/Leis/L4320compilado.htm.

BOTELHO, R.. Determinantes do comportamento fiscal dos estados brasileiros. Dissertação de Mestrado. São Paulo: Universidade de São Paulo - Faculdade de Economia, Administração e Contabilidade. 2002.

DOWNS, Anthony. Uma teoria econômica da democracia. Edusp. São Paulo, 1999.

FAVERET, A. C. de S. C. A vinculação constitucional de recursos para a saúde: avanços, entraves e perspectivas. Ciência \& Saúde Coletiva, Rio de Janeiro: Associação Brasileira de Pós-Graduação em Saúde Coletiva, v. 8, n. 2, 2003. Disponível em: http://www. scielo.br/scielo.

FIALHO, Tânia Marta Maia. Ciclos Políticos: uma resenha. Revista de Economia Política, vol. 19, n 2, abril-junho/1999.

GIACOMONI, James. Orçamento Público. São Paulo. Editora Atlas. 14a edição. 2007.

HAIR, Júnior, J.F.; ANDERSON, R.E.; TATHAM, R.L.; BLACK, W.C. Análise multivariada de dados. 5.ed. Bookman, 2005.

HIBBS, Douglas A. "Political parties and macroeconomic policy". American Political.Science Review, v.71, n.4, p.1467-1487, Dec. 1977.

HSIAO, Cheng. Analysis of panel data. Cambridge: Cambridge University Press, 1986.

IBGE - $\underline{\text { www.ibge.gov.br }}$

IPEADATA - www.ipeadata.gov.br

LAKATOS, E.M.; MARCONI, M.A. Metodologia científica. 4.ed. São Paulo: Atlas, 2004. 
NAKAGUMA, Marco Y. Ciclos políticos e resultados eleitorais. USP. São Paulo, 2010.

NORDHAUS, William D. "The Political Business Cycle". Review of Economic Studies, Bristal, England, v.42, p.169-190, Abr. 1975.

PELlini, Ana Maria. Os Sistemas de Planejamento, Execução e Controle da Gestão Pública, uma nova proposta. Revista ConTexto, Porto Alegre, v.3, n.4, p.1-2, mar.2006.

PISCITELLI, Roberto Bocaccio; Timbó, Maria Zulene Farias. Contabilidade Pública: Uma Abordagem da Administração Pública Financeira. São Paulo. Editora Atlas. 10ª edição. 2009.

RICHARDSON, R.J. Pesquisa social: métodos e técnicas. São Paulo: Atlas, 1999.

ROGOFF, Kenneth. Equilibrium Political Budget Cycles. American Economic Review, v.80, n.1, p.21-36, março de 1990.

ROGOFF, Kenneth; SIBERT, Anne. Elections and macroeconomic policy cycles. Review of economic studies. №55, 1988.

SAKURAI, Sergio Naruhiko. Political business cycles: procurando evidências empíricas para os municípios paulistas. Revista de Economia Aplicada, n. 1, v. 11, p. 27-54, 2007.

SILVA, Sibele Leandra Penna. Ciclo Político-Orçamentário: Um Estudo em Municípios do Estado de Minas Gerais - 2000/2008. Dissertação de Mestrado. Viçosa. 2010.

SOUSA, R.G. Gastos públicos e desenvolvimento humano nos estados do Brasil. Dissertação de Mestrado. João Pessoa. 2014.

TESOURO NACIONAL - www.tesouro.fazenda.gov.br/contas-anuais

TRIBUNAL SUPERIOR ELEITORAL - www.tse.gov.br

VIANNA, Ana Luiza. Abordagens metodológicas em políticas públicas. Revista de Administração Pública. Rio de Janeiro, v.30, n.2, 1996.

WILGES, Ilmo José. Noções de Direito Financeiro: O orçamento Público. Porto Alegre: Sagra-Luzzatto, 1995. 